\title{
Biodiversity of periphytic cyanobacteria and algae assemblages in polar region: a case study of the vicinity of Arctowski Polish Antarctic Station (King George Island, Antarctica)
}

\author{
Elżbieta Zębek ${ }^{1}$ (D) Agnieszka Napiórkowska-Krzebietke ${ }^{2}$ (D) \\ Aleksander Świątecki ${ }^{3}$ (D) Dorota Górniak ${ }^{3}$ (D)
}

Received: 7 February 2021 / Revised: 1 June 2021 / Accepted: 2 June 2021 /

Published online: 3 July 2021

(c) The Author(s) 2021

\begin{abstract}
This study was carried out on periphytic cyanobacteria and algae assemblages of microbial mats in streams and small water bodies during the Antarctic summer of 2019 in the vicinity of Ecology Glacier (King George Island, Antarctica). The significantly diversified assemblages between the microbial mats of small water bodies and streams were observed. The higher biomass and proportion of periphytic cyanobacteria with Planktothix agardhii as dominant species were found in the streams at lower mean water temperature and higher nutrient content while diatoms generally dominated in the small water bodies (primarily Fragilaria capucina). Chlorophyta also reached a significant proportion in the total biomass of periphyton with dominant species of Prasiola crispa and Keratococcus mucicola. The growth of periphytic cyanobacteria and algae was determined mainly by type of substrate, water temperature and nutrient concentrations. The results also suggest the phenomenon of nutrient uptake by these assemblages from the waters, confirmed by the negative correlations between some species and nutrients (TN, TP, N-NH, $\left.\mathrm{P}_{4} \mathrm{PO}_{4}\right)$. A large share of commonly occurring periphytic species and limitation of typically polar ones, suggest progressive changes in the eutrophication of Antarctic waters caused by the global climate change and increased pollution in the environment. Therefore, these areas should be subject to a special legal protection, preceded by detailed research of these ecosystems.
\end{abstract}

Keywords Ecology $\cdot$ Cyanobacteria and algae $\cdot$ Small water bodies $\cdot$ Streams $\cdot$ Global climate changes $\cdot$ Legal status

Communicated by Anurag chaurasia.

Agnieszka Napiórkowska-Krzebietke

a.napiorkowska-krzebietke@infish.com.pl

Extended author information available on the last page of the article 


\section{Introduction}

Antarctica is a territory not subjected to a state sovereignty. It is polar and subpolar area in the southern hemisphere, which consists of the Antarctic continent and the surrounding seas with many islands. Antarctica is an area important for strategic reasons due to numerous mineral resources, which for many countries are sufficient and often the only reason for territorial claims to these areas (Symonides 2008; Zawidzka-Łojek 2018). The political and legal status of Antarctica was determined by the Antarctic Treaty, adopted in 1959 in Washington (Antarctic Treaty System, ATS, 1961), regulating activities in this region. Under the provisions of the Treaty, Antarctica may be used only for peaceful purposes. In particular, all military activities or the creation of military bases are prohibited (Article 1). Treaty provides freedom of the scientific investigations and cooperation in this field, as well as exchange of information on research plans in Antarctica; exchange of scientific personnel, exchange of data and results of scientific observations in Antarctica and free access to them (Articles 2 and 3). According to the provisions of the Treaty, no State may claim rights to territorial sovereignty in Antarctica (Article 4). Additional international agreements regulating the legal status and activities in the Antarctic area are the Protocol on Environmental Protection to the Antarctic Treaty signed in Madrid on October 4, 1991, Convention on the protection of Antarctic seals signed in London on June 1, 1972 and Convention on the conservation of Antarctic marine living resources signed in Canberra on May 20, 1980 (Marciniak 2017; Świątecki et al. 2019).

Antarctica is characterized by a natural uniqueness, but also a progressive degradation of these areas caused mainly by climate change (Ciechanowicz-McLean 2017). For this reason, numerous scientific investigations are conducted in these areas, especially because of the need to protect them, which indicate their progressive degeneration due to a constant increase in temperature (Bosello et al. 2007; Cannone et al. 2018; Szafraniec 2018; Lowry et al. 2019; Świątecki et al. 2019). In the field of biological research, the main topics are marine and land biology, paleontology and monitoring of selected groups of flora and fauna (Rakusa-Suszczewski 2005). A special place of polar research is the area of King George Island, where the station named after Henryk Arctowski in the area of the Ecology Glacier is situated. This area is a kind of "hot spot" of global climate change, allows to track, among others the deglaciation process and its impact on the functioning of the polar ecosystem (Świątecki et al. 2012). Recently, the microbiological and algological studies have become very important, and they focus on determining the structural and functional characteristics of these small-sized groups of organisms. Organisms living in these areas are characterized by unique properties, including high resistance to extreme environmental factors such as low temperature, ultraviolet radiation, drying, low availability of nutrients (Grzesiak et al. 2015; Gawor et al. 2016; Grzesiak 2017). Microorganisms taken out of the melting water from the foreland of the glacier usually form heterogeneous microbial mats in the watercourses. In addition to prokaryotic microorganisms and single and multicellular algae, the presence of numerous species of protozoans, crustacean zooplankton, nematodes and tardigrades has been observed (Mieczan 2013).

The basis of microfilm mats is often composed of organic and mineral matter constituting a habitat for cyanobacteria and periphytic algae. The same matter forms a structural system of mats in streams and small water bodies located in the vicinity of the glacier. The living organisms are sensitive to environmental factors, i.e. temperature, type of substrate, oxygenation, nutrient content. In addition, the water current is very important because it facilitates immigration and subsequent colonization of periphytic algae, as well 
as stimulates physiological processes, including nutrient uptake and photosynthesis at higher velocities (Biggs 2000; Stevenson et al. 2006; Szabo et al. 2007; Komulaynen 2009; Zębek 2013). Thus, cyanobacteria and periphytic algae become good indicators of changes in the aquatic environment in the foreland of the glacier. We hypothesized that the changes in environmental conditions of glacier region affect the growth and diversity of periphytic assemblages inhabiting the microbial mats in streams and small water bodies. The aim of the study was to describe the diversity of periphytic cyanobacteria and algae assemblages inhabiting the microbial mats in streams and small water bodies in the vicinity of Arctowski Polish Antarctic Station (King George Island, Antarctica). We also determined the relationships between periphytic cyanobacteria and algae and physiochemical water parameters because these are important factors in the creation of suitable environmental conditions for their growth and development.

\section{Materials and methods}

Ecology Glacier is situated at the western shore of Admiralty Bay in the Antarctic Specially Protected Area, on King George Island, South Shetland Archipelago, Antarctica (Fig. 1). It is subjected to annual surface snow melt like other glaciers in the vicinity (Braun and Gossmann 2002). The studies were carried out in the vicinity of this glacier (Fig. 2). Samples were taken in the Antarctic summer (March/April) 2019 at twenty sites in streams, S (1-15) and small water bodies, SWB (1-5) (Fig. 2, Table 1). Streams were located on the slope of Upłaz moraine, from the south and north side moraine of the Ecology Glacier, petrified forest and as an inflow to the drinking water reservoir. Small water bodies included the reservoir system at the ornithological site (penguin) and at the lateral moraine of the glacier (southern).

The microbial mats were taken from mineral and organic substrates from the streams and small water bodies. The samples were rinsed and preserved using Lugol and formaldehyde solutions. A total of 20 samples were collected. Additionally, the mat samples were taken for analyses of hydration degree using a flat mesh made of metal with an area of 5 $\mathrm{cm}^{2}$. The mat was trimmed with scissors and placed in a pre-weighed $6 \mathrm{~cm}$ diameter Petri dish. In the laboratory, each Petri dish with the mat was weighed (wet weight), and then, it was dried at $50^{\circ} \mathrm{C}$ overnight to constant weight. After drying, the dry mat was weighed (dry weight). The percentage of water (\% hydration) in each mat was then calculated. The basic physical and chemical water parameters were measured directly at the sampling sites. The surface water temperature, conductivity, dissolved oxygen (DO) and $\mathrm{pH}$ were measured in situ at the sampling sites using the WTW GmbH (Germany) equipment. The concentration of nutrients (TN, N-NH , TP and $\mathrm{P}-\mathrm{PO}_{4}$ ) was measured in the laboratory using a NOVA 400 spectrophotometer (Merck).

Periphytic cyanobacteria and algae from the mats were analyzed in this study. The mats were characterized by a layered structure inhabiting by filamentous and colonial cyanobacteria and chlorophytes forming the natural substrate for diatoms. The samples were shaken carefully in distilled water to separate these algae (including diatoms). Qualitative and quantitative determinations were performed with an Alphaphot YS2 optical microscope at magnifications of $100 \times, 200 \times, 400 \times$ and $1000 \times$. Diatom preparations followed the standard procedures described by Battarbee (1979). Cyanobacteria and algae biomass was calculated based on biovolume measurements by comparing with their geometric shapes 


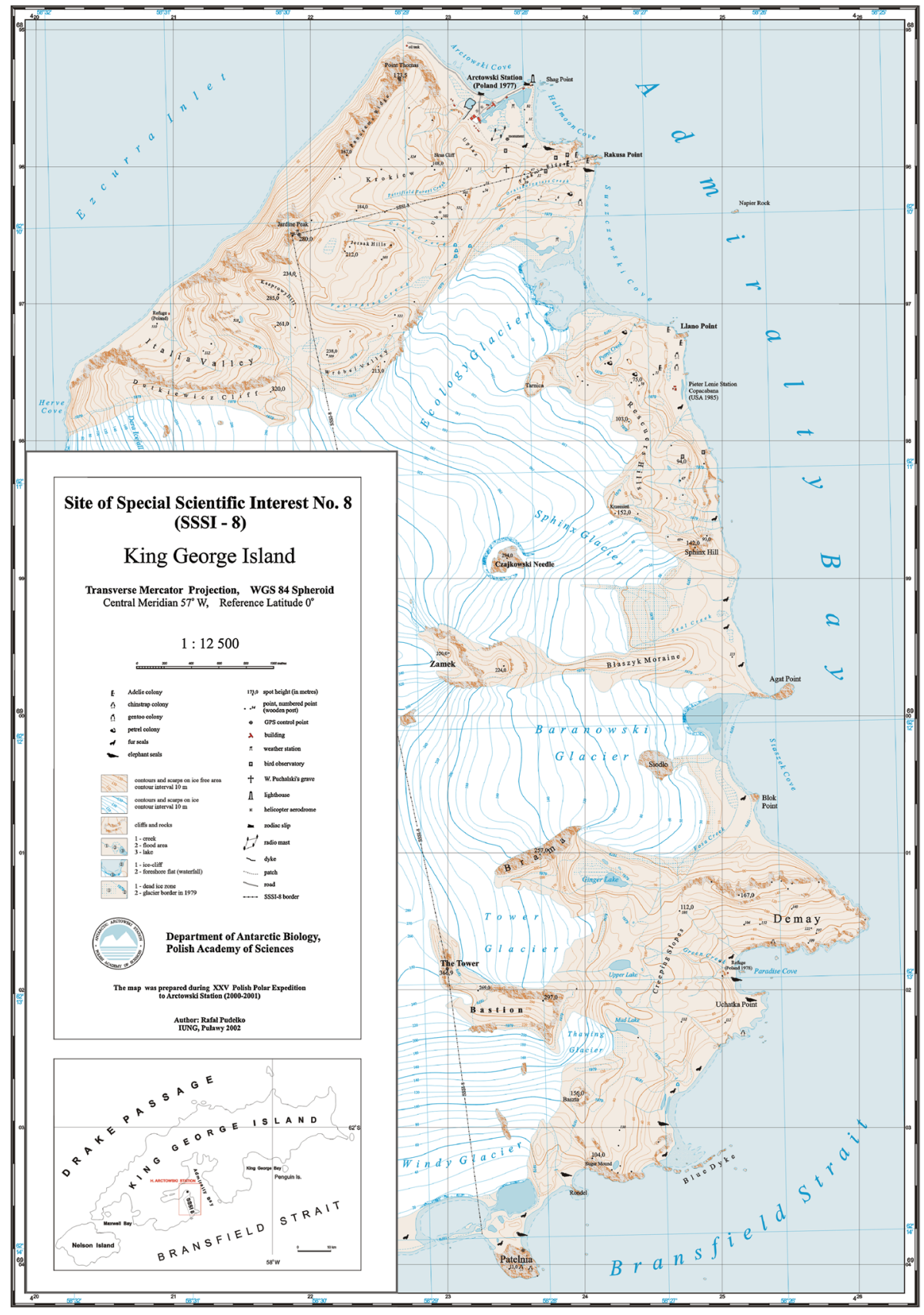

Fig. 1 Location of the Ecology Glacier in the neighbourhood of Arctowski Polish Antarctic Station (King George Island, Antarctica) 

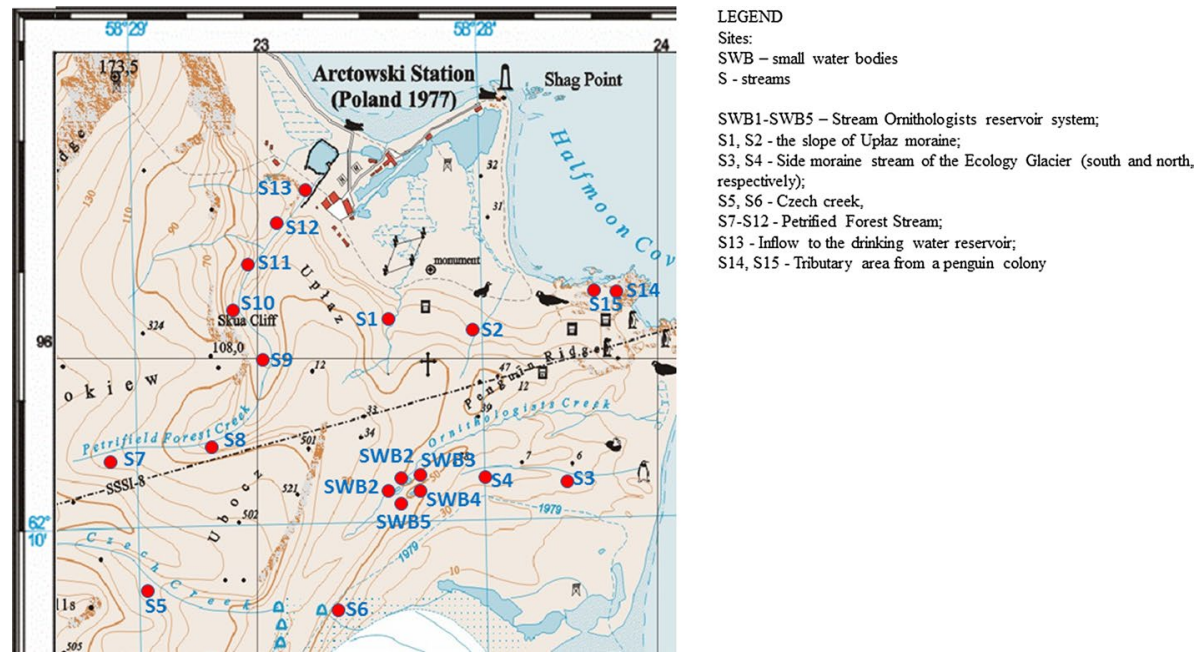

Fig. 2 The map with sampling sites of small water body and stream mats in the vicinity of Ecology Glacier

(Napiórkowska-Krzebietke and Kobos 2016). The mean biomass was calculated for 10 individuals of each periphytic cyanobacteria and algae species and expressed in $\mathrm{mg} \mathrm{cm}^{-2}$.

Biodiversity of assemblages included species richness, and diversity indices: Shannon index (Shannon 1948) and evenness (Pielou 1966) which were calculated based on biomass of individual taxa. Dominance of cyanobacteria and algae species was classified according to their relative biomass (\%) and divided into 5 classes (class $\mathrm{I}-0-20 \%$, class II- $21-40 \%$, class III- $41-60 \%$, class IV-61-80\%, class V- $81-100 \%$ of the total biomass). Biomass of periphytic cyanobacteria and algae groups and dominant species were correlated with physical and chemical water parameters (water temperature, $\mathrm{pH}$, conductivity, TN, $\mathrm{N}-\mathrm{NH}_{4}$, TP and $\mathrm{P}_{-} \mathrm{PO}_{4}$ ) using nonparametric methods because these data are not normally distributed.

The analyses of difference in taxonomic structure of all mats were performed by the use of cluster analysis based on a percent similarity within Multivariate Statistical Package (MVSP) and Non-Metric Multidimensional Scaling (NMDS) based on Bray-Curtis distance. To reduce the number of variables, a forward selection procedure was performed using the Monte Carlo test with 999 permutations. Relationships were confirmed by calculating Spearman's rank correlation coefficient $(\mathrm{p}<0.05)$ with STATISTICA version 8 , and then with the canonical correspondence analysis (CCA). All parameters were standardized using log $(\mathrm{x}+1)$-transformation. Response data were compositional and had a gradient 1.6 SD units long, thus, such a unimodal method could be used. Finally, these relationships were presented on a biplots graph using Canocco for Windows 5.0 software.

\section{Results}

\section{Physiochemical water parameters}

In the small water bodies, the mean values of water temperature $\left(4.6^{\circ} \mathrm{C}\right)$ and $\mathrm{pH}(7.66)$ (Table 2) were generally higher than in the streams. The other parameters were, in turn, 
Table 1 Characteristics of the study area

\begin{tabular}{|c|c|c|c|}
\hline Site & Coordinates & Name & Eco-region/area \\
\hline SWB1 & $\begin{array}{l}62.16486 \mathrm{~S} \\
58.47025 \mathrm{~W}\end{array}$ & Stream Ornithologists reservoir system & I \\
\hline SWB2 & $\begin{array}{l}62.16572 \mathrm{~S} \\
58.47033 \mathrm{~W}\end{array}$ & Stream Ornithologists reservoir system & I \\
\hline SWB3 & $\begin{array}{l}62.16603 \mathrm{~S} \\
58.47,097 \mathrm{~W}\end{array}$ & Stream Ornithologists reservoir system & I \\
\hline SWB4 & $\begin{array}{l}62.16603 \mathrm{~S} \\
58.47067 \mathrm{~W}\end{array}$ & Stream Ornithologists reservoir system & I \\
\hline SWB5 & $\begin{array}{l}62.16608 \mathrm{~S} \\
58.47033 \mathrm{~W}\end{array}$ & Stream Ornithologists reservoir system & I \\
\hline S1 & $\begin{array}{l}62.21869 \mathrm{~S} \\
58.35080 \mathrm{~W}\end{array}$ & Stream on the slope of Upłaz moraine & II \\
\hline $\mathrm{S} 2$ & $\begin{array}{l}62.16886 \mathrm{~S} \\
58.48086 \mathrm{~W}\end{array}$ & Stream on the slope of Upłaz moraine & II \\
\hline S3 & $\begin{array}{l}62.16700 \mathrm{~S} \\
58.46867 \mathrm{~W}\end{array}$ & Side moraine stream of the Ecology Glacier (south-S) & III \\
\hline S4 & $\begin{array}{l}62.16789 \mathrm{~S} \\
58.46739 \mathrm{~W}\end{array}$ & Side moraine stream of the Ecology Glacier (north-N) & IV \\
\hline S5 & $\begin{array}{l}62.16931 \mathrm{~S} \\
58.47725 \mathrm{~W}\end{array}$ & Czech creek & V \\
\hline S6 & $\begin{array}{l}62.16892 \mathrm{~S} \\
58.47225 \mathrm{~W}\end{array}$ & Czech creek & V \\
\hline S7 & $\begin{array}{l}62.16675 \mathrm{~S} \\
58.4918 \mathrm{~W}\end{array}$ & $\begin{array}{l}\text { Petrified Forest Stream } \\
\text { (the highest/beginning point) }\end{array}$ & VI \\
\hline S8 & $\begin{array}{l}62.16681 \mathrm{~S} \\
58.49175 \mathrm{~W}\end{array}$ & Petrified Forest Stream & VI \\
\hline S9 & $\begin{array}{l}62.16689 \mathrm{~S} \\
58.48817 \mathrm{~W}\end{array}$ & Petrified Forest Stream & VI \\
\hline S10 & $\begin{array}{l}62.16508 \mathrm{~S} \\
58.47811 \mathrm{~W}\end{array}$ & Petrified Forest Stream & VI \\
\hline S11 & $\begin{array}{l}62.16789 \mathrm{~S} \\
58.48356 \mathrm{~W}\end{array}$ & Petrified Forest Stream & VI \\
\hline S12 & $\begin{array}{l}62.16728 \mathrm{~S} \\
58.48253 \mathrm{~W}\end{array}$ & Petrified Forest Stream & VI \\
\hline S13 & $\begin{array}{l}62.16667 \mathrm{~S} \\
58.48094 \mathrm{~W}\end{array}$ & Inflow to the drinking water reservoir (the lowest/ending point) & VI \\
\hline S14 & $\begin{array}{l}62.16200 \mathrm{~S} \\
58.46222 \mathrm{~W}\end{array}$ & Tributary area from a penguin colony & VII \\
\hline S15 & $\begin{array}{l}62.16219 \mathrm{~S} \\
58.46239 \mathrm{~W}\end{array}$ & Tributary area from a penguin colony & VII \\
\hline
\end{tabular}

$S W B$ small water body, $S$ stream

characterized by lower ranges of values and coefficients of variations. Electrolytic conductivity ranged from 72 to $350 \mu \mathrm{S} \mathrm{cm} \mathrm{cm}^{-1}$. Total nitrogen content amounted maximally to $4.10 \mathrm{mg} \mathrm{dm}^{-3}$, and ammonium maximally to $0.38 \mathrm{mg} \mathrm{dm}^{-3}$, which was about two times and six times less than their maxima recorded in the streams. Much larger differences concerned phosphorus. TP content ranged from 0.09 to $0.18 \mathrm{mg} \mathrm{dm}^{-3}$, whereas 
Table 2 Physical and chemical parameters in the streams and small water bodies in March/April 2019

\begin{tabular}{|c|c|c|c|c|c|}
\hline Parameters & Minimum & Maximum & Mean & $\pm \mathrm{SD}$ & $\mathrm{CV}(\%)$ \\
\hline \multicolumn{6}{|l|}{ Small water bodies } \\
\hline Temperature, $\mathrm{T}\left({ }^{\circ} \mathrm{C}\right)$ & 3.7 & 5.1 & 4.6 & 0.55 & 12 \\
\hline $\mathrm{pH}$ & 6.98 & 8.83 & 7.66 & 0.72 & 9 \\
\hline $\begin{array}{l}\text { Electrolytic conductivity, EC } \\
\left(\mu \mathrm{S} \mathrm{cm}^{-1}\right)\end{array}$ & 72 & 350 & 209.6 & 120.83 & 58 \\
\hline Total nitrogen, $\mathrm{TN}\left(\mathrm{mg} \mathrm{dm}^{-3}\right)$ & 0.70 & 4.10 & 1.86 & 1.30 & 70 \\
\hline Ammonium, $\mathrm{N}-\mathrm{NH}_{4}\left(\mathrm{mg} \mathrm{dm}^{-3}\right)$ & 0.03 & 0.38 & 0.15 & 0.14 & 92 \\
\hline Total phosphorus, TP $\left(\mathrm{mg} \mathrm{dm}^{-3}\right)$ & 0.09 & 0.18 & 0.12 & 0.04 & 34 \\
\hline Phosphates, $\mathrm{P}-\mathrm{PO}_{4}\left(\mathrm{mg} \mathrm{dm}^{-3}\right)$ & 0.02 & 0.07 & 0.04 & 0.02 & 58 \\
\hline \multicolumn{6}{|l|}{ Streams } \\
\hline Temperature, $\mathrm{T}\left({ }^{\circ} \mathrm{C}\right)$ & 1.3 & 5.6 & 3.3 & 1.42 & 43 \\
\hline $\mathrm{pH}$ & 6.50 & 8.31 & 7.09 & 0.54 & 8 \\
\hline $\begin{array}{l}\text { Electrolytic conductivity, EC } \\
\left(\mu \mathrm{S} \mathrm{cm}^{-1}\right)\end{array}$ & 70 & 1514 & 268.2 & 397.52 & 148 \\
\hline Total nitrogen, $\mathrm{TN}\left(\mathrm{mg} \mathrm{dm}^{-3}\right)$ & 0.70 & 8.40 & 2.30 & 2.22 & 99 \\
\hline Ammonium, $\mathrm{N}-\mathrm{NH}_{4}\left(\mathrm{mg} \mathrm{dm}^{-3}\right)$ & 0.02 & 2.30 & 0.24 & 0.59 & 249 \\
\hline Total phosphorus, TP $\left(\mathrm{mg} \mathrm{dm}^{-3}\right)$ & 0.09 & 4.30 & 0.60 & 1.27 & 212 \\
\hline Phosphates, $\mathrm{P}_{-}-\mathrm{PO}_{4}\left(\mathrm{mg} \mathrm{dm}^{-3}\right)$ & 0.02 & 1.33 & 0.19 & 0.40 & 210 \\
\hline
\end{tabular}

$S D$ standard deviation, $C V$ coefficient of variation

phosphates ranged from 0.02 to $0.07 \mathrm{mg} \mathrm{dm}^{-3}$. Based on averages, the phosphorus content was about five times lower in the small water bodies than in the streams.

The mean water temperature in the streams ranged from 1.3 to $5.6^{\circ} \mathrm{C}$ with an average of $3.3^{\circ} \mathrm{C}$ (Table 2). The $\mathrm{pH}$ changed also in a narrow range (6.50-8.31), whereas the changes in an electrolytic conductivity were markedly wider i.e. from 70 to 1514 $\mu \mathrm{S} \mathrm{cm}^{-1}$, with a very high coefficient of variation (148\%). A high variability was also recorded in nutrient concentrations. Total nitrogen content ranged from 0.70 to $8.40 \mathrm{mg} \mathrm{dm}^{-3}$, while ammonium from 0.02 to $2.30 \mathrm{mg} \mathrm{dm}^{-3}$. Similarly, a wide range of concentration was also noted in the case of phosphorus, i.e. TP from 0.09 to $4.30 \mathrm{mg} \mathrm{dm}^{-3}$ and phosphates from 0.02 to $1.33 \mathrm{mg} \mathrm{dm}^{-3}$. The coefficient of variation in nitrogen and phosphorus content maximally amounted to $249 \%$ and $212 \%$, respectively. The extremely high values of EC and nutrients were usually recorded at sites S14 and $\mathrm{S} 15$, i.e. in the area of a penguin colony.

The studied microbial mats differed in their weight and hydration (Table 3). The small water body mats were characterized by wet weight in the range of $0.140-0.240 \mathrm{~g}$ and dry weight of $0.008-0.120 \mathrm{~g}$. The degree of hydration was, thus, differentiated. The lowest hydration was noted at site SWB3 (46\%), whereas the highest at site SWB5 $(96 \%)$.

The ranges of wet and dry weights in case of stream mats were markedly wider. The lowest weights $(0.090 \mathrm{~g}$ and $0.011 \mathrm{~g}$ for wet and dry, respectively) had mat at sites S3 and S11, respectively. The hydration amounted then 52\% and $97 \%$. The highest wet weight $(1.324 \mathrm{~g})$ with hydration of $79 \%$ was recorded for mat at site S2. The highest dry weight $(0.580 \mathrm{~g})$, in turn, was recorded for mat at site S7 with the lowest hydration of $41 \%$. The highest degree of hydration amounted to 97\% (sites S11 and S15). 
Table 3 Properties of the small water bodies (SWB) and stream (S) mats

\begin{tabular}{llll}
\hline Site & Wet weight $(\mathrm{g})$ & Dry weight $(\mathrm{g})$ & Hydration $(\%)$ \\
\hline SWB1 & 0.240 & 0.120 & 50 \\
SWB2 & 0.210 & 0.074 & 65 \\
SWB3 & 0.140 & 0.075 & 46 \\
SWB4 & 0.160 & 0.062 & 61 \\
SWB5 & 0.190 & 0.008 & 96 \\
S1 & 0.170 & 0.056 & 67 \\
S2 & 1.324 & 0.284 & 79 \\
S3 & 0.090 & 0.043 & 52 \\
S4 & 0.160 & 0.063 & 61 \\
S5 & 0.355 & 0.143 & 60 \\
S6 & 0.128 & 0.017 & 87 \\
S7 & 0.990 & 0.580 & 41 \\
S8 & 0.277 & 0.159 & 43 \\
S9 & 0.150 & 0.067 & 55 \\
S10 & 0.438 & 0.016 & 96 \\
S11 & 0.426 & 0.011 & 97 \\
S12 & 0.285 & 0.032 & 89 \\
S13 & 0.339 & 0.136 & 60 \\
S14 & 1.000 & 0.259 & 74 \\
S15 & 0.530 & 0.014 & 97 \\
\hline
\end{tabular}

\section{Periphytic cyanobacteria and algae on mats}

Generally, the periphytic assemblages inhabiting the microbial mats in the region of Arctowski Polish Antarctic Station at the King George Island (Antarctica) comprised of three phyla: Cyanobacteria, Bacillariophyta and Chlorophyta. Their total biomass ranged from $0.16 \mathrm{mg} \mathrm{cm}^{-2}$ at site SWB2 to $1.25 \mathrm{mg} \mathrm{cm}^{-2}$ at site SWB5 on the small water body mats (Fig. 3A). A higher total biomass and higher range was found on the stream mats, where the values changed from $0.22 \mathrm{mg} \mathrm{cm}^{-2}$ to $3.81 \mathrm{mg} \mathrm{cm}^{-2}$ at sites $\mathrm{S} 9$ and S5, respectively.

Analogues to changes in the total biomass, the dominance structure also differed markedly between the studied sites (Fig. 3B). Diatoms dominated the assemblages on mats at the sites SWB1-SWB3 forming from 56 to $93 \%$ of the total biomass. Cyanobacteria share ranged there from 7 to $44 \%$, and green algae were absent. At site SWB4 cyanobacteria slightly prevailed (57\%), whereas at site SWB5 green algae formed $66 \%$ of the total biomass, then cyanobacteria $31 \%$ and diatoms only $3 \%$.

Total of 42 taxa were recorded. A higher species richness was generally noted on mats at SWB 1-5 (9-22) than mats at S1-15 (6-18). The values of Shannon index changed in a narrower (0.761-1.367) and wider (0.112-1.901) range, respectively. In analogy, evenness ranged from 0.280 to 0.505 (SWB1-SWB5) and from 0.042 to 0.717 (S1-S15). Comparing the biodiversity on mats in both types of waters, the average values of diversity indices were similar, i.e. Shannon index of 1.105 and 1.139 and evenness of 0.395 and 0.453 , respectively. The prevailing dominance (70-99\%) of cyanobacteria was found on the stream mats at sites S1, S3, S4, S5, S9 and S14. Diatoms 


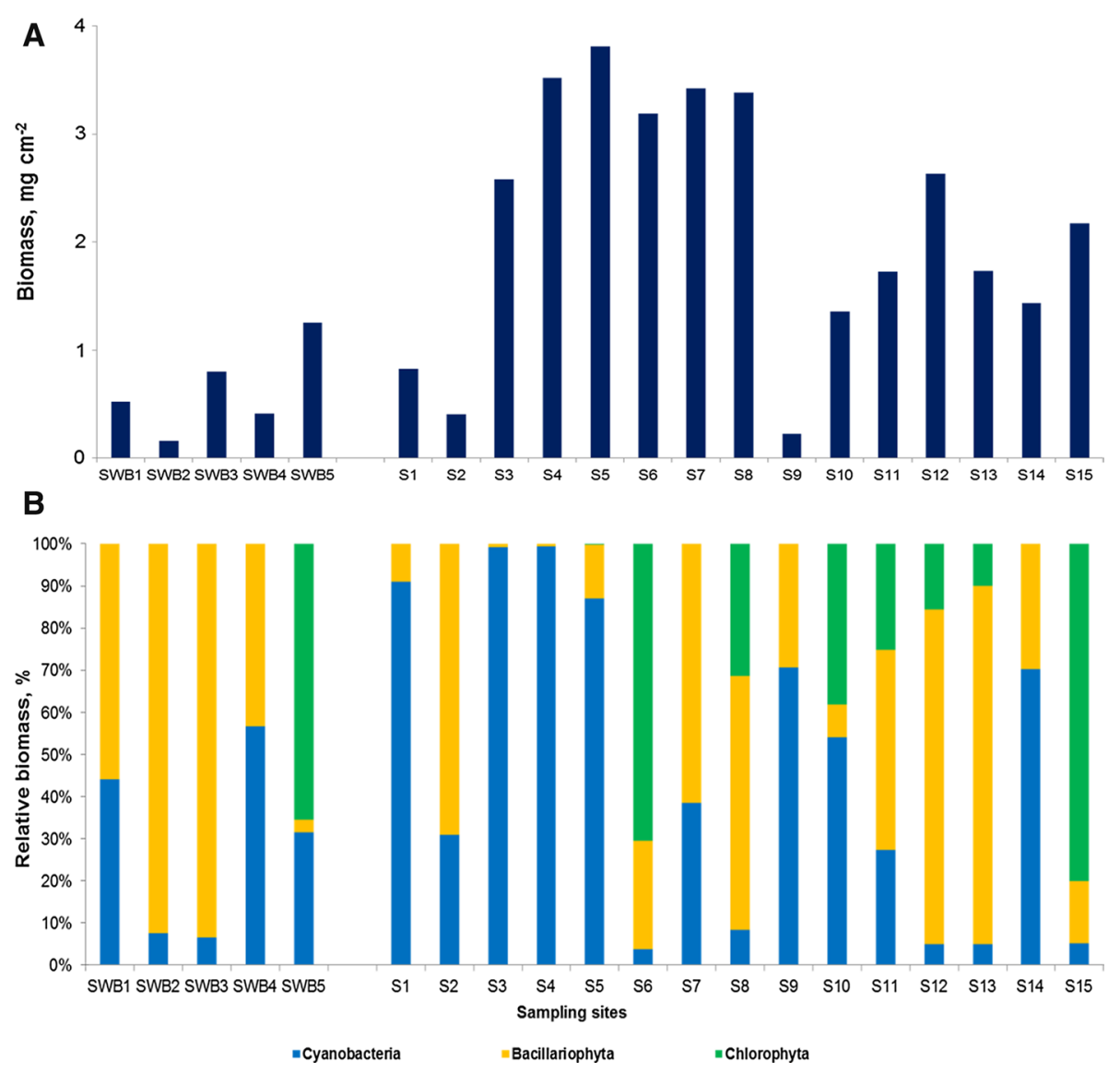

Fig. 3 Total biomass (A) and structure (B) of periphytic assemblages on small water bodies (sites SWB1SWB5) and stream mats (sites S1-S15)

dominated on mats at sites: S2, S7, S8, S12 and S13 forming about $60-85 \%$ of the total biomass. Only mats at sites S6 and S15 were dominated by green algae (70-80\%). The rest mats were characterized by co-domination of cyanobacteria and diatoms (S10) or all taxonomic groups (S11).

Cyanobacteria were represented by five species and primarily by filamentous Planktothix agardhii (Table 4). This species was present on almost all mats and predominated the periphytic assemblages at sites S1, S3-S5 with relative biomass of $81-100 \%$ included into the class V. The another species was Planktolyngbya limnetica with the class I of 0-20\% relative biomass. Other cyanobacteria, i.e. Pseudanabaena catenata, Oscillatoria sancta and Microcoleus autumnalis were less abundantly recorded on the mats.

Among diatoms, the most abundant was Fragilaria capucina especially on the small water body mats (SWB1-SWB3) where relative biomass of 41-60\% was included in the class III and of $61-80 \%$ in class IV. The other species such as Planothidium lanceolatum, Achnanthidium pyrenaicum, Tabularia tabulata and Pinnularia microstauron were the most often occurring diatoms which reached the relative biomass fitting in the classes I-III. 
Table 4 Cyanobacteria and algae species inhabiting small water body (SW1-L50) and stream (S1-S15) mats

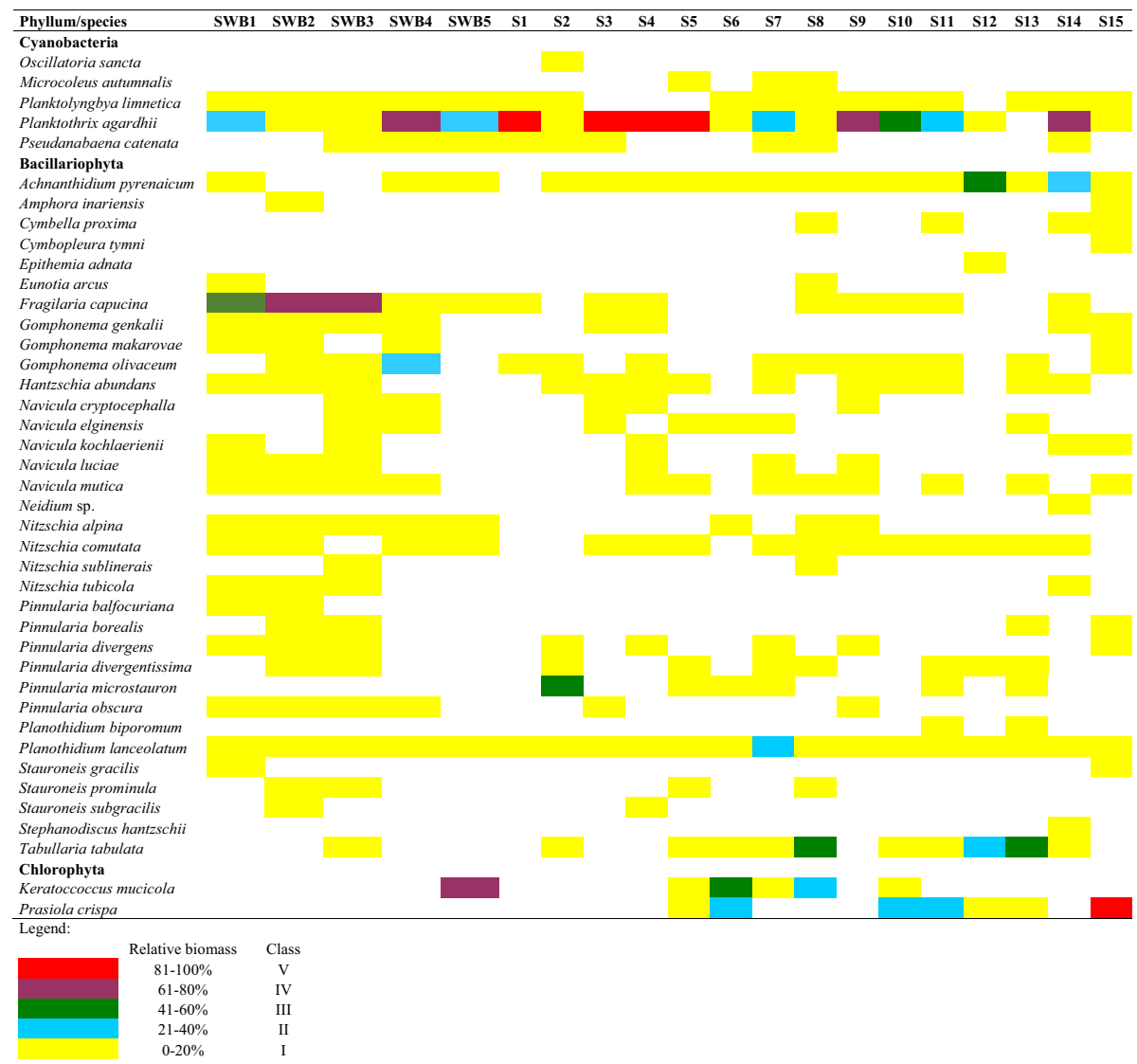

The biomasses of the rest species were qualified to class I. Among them, the most often noted were primarily Gomphonella olivacea, Hantzschia abundans, Nitzschia commutata.

The last group, i.e. chlorophytes, was represented by Prasiola crispa and Keratococcus mucicola. The highest biomass of $P$. crispa was included into class V (81-100\%) at site S15 whereas biomass of $K$. mucicola into class IV (61-80\%) at site SWB5.

A percent similarity based cluster analysis of the taxonomic structure indicated a division in three separate groups of mats (Fig. 4). The first group contained the stream mats, including sites S3-S4 with the highest similarity (85\%) and S14, sites S10-S11, and sites S5, S7. The second group comprises the stream mats from sites S12, S13, S15, and S6, S8 and exceptionally one small water body mat (SWB5). The small water body mats were generally gathered as the third group which included sites SWB1-SWB4, the most similar were also periphytic assemblages from stream mats S1, S2 and S9. However, the highest similarity (70\%) was found between SWB4 and S1.

The analysis of taxonomic structure and dominating species using NMDS based on Bray-Curtis distance allowed to distinguish the main factors differentiating the mats (Fig. 5). The diatoms $F$. capucina and G. olivacea were connected the most with sites in the small water bodies (SWB1-SWB4) and streams (S1, S9 and S14). The whole phylum 


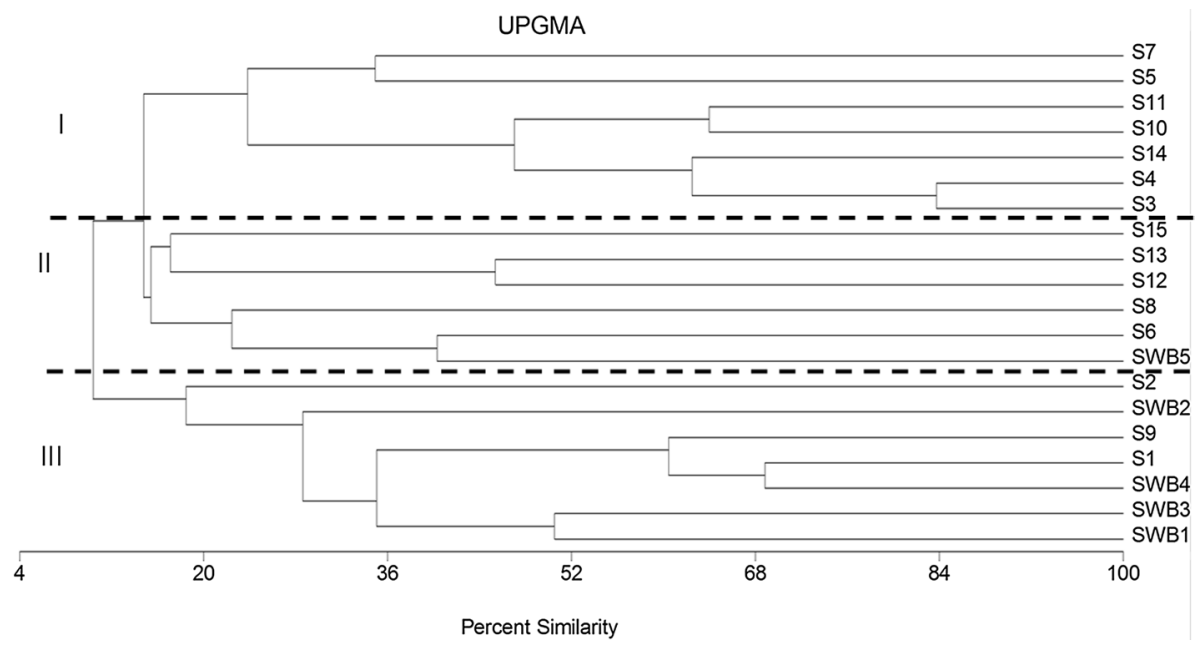

Fig. 4 Hierarchical cluster analysis based on percent similarity of species

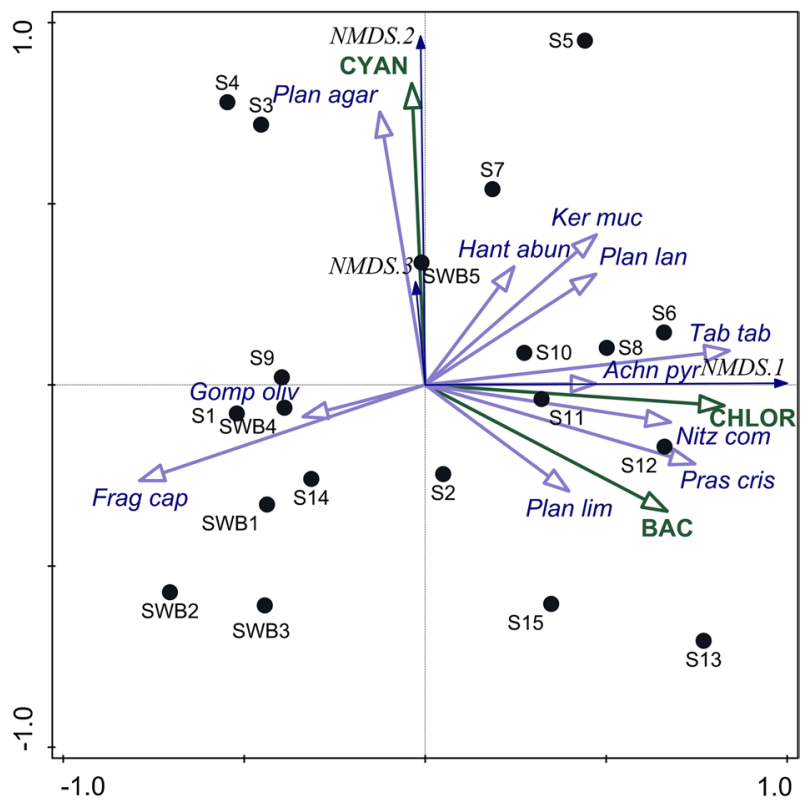

Fig. 5 The Non-metric multidimensional scaling (NMDS) analysis plot of taxonomic structure of the periphytic assemblages of mats, (the stress value 0.085823). Codes of variables: CYAN-Cyanobacteria, BAC-Bacillarophyta, CHLOR-Chlorophyta, Achn pyr-Achnanthidium pyrenaicum, Frag cap-Fragilaria capucina, Plan lan-Planothidium lanceolatum, Tab tab-Tabularia tabulata, Gomp oliv-Gomphonella olivacea, Hant abun-Hantzschia abundans, Nitz com-Nitzschia commutata, Pras cris-Prasiola crispa, Ker тис-Keratococcus mucicola, Plan lim-Planktolyngbya limnetica, Plan agar-Planktothix agardhii; $\mathrm{pH}$-water reaction, $\mathrm{T}$-water temperature, EC-electrolytic conductivity, N-NH4-ammonium, TN-total nitrogen, P-PO4—phosphates, TP-total phosphorus; codes of mats: SWB1-SWB5-small water bodies mats, S1-S15-stream mats 
Cyanobacteria and dominating P. agardhii were related to sites S3 and S4. The rest of analyzing species and phyla corresponded more or less with the other sites.

\section{Relationships between periphytic cyanobacteria and algae and physiochemical water parameters}

Statistically significant relationships (Spearman coefficient) were established between selected species of periphytic cyanobacteria and algae biomass and physiochemical water parameters $(\mathrm{N}=20, \mathrm{p}<0.05)$ (Table 5). Here, A. pyrenaicum was positively correlated with $\mathrm{TN}(\mathrm{r}=0.481)$. In contrast, negative correlations were recorded between $P$. agardhii and water temperature $(\mathrm{r}=-0.458)$, P. lanceolatum and $\mathrm{pH}(\mathrm{r}=-0.531), K$. mucicola and $\mathrm{N}-\mathrm{NH}_{4}(\mathrm{r}=-0.493)$, G. olivacea, N. cryptocephala, P. obscura and $\mathrm{P}_{-} \mathrm{PO}_{4}(\mathrm{r}=-0.571$, $\mathrm{r}=-0.478$ and $\mathrm{r}=-0.529$, respectively), and G. olivacea, P. divergens, P. obscura and TP $(\mathrm{r}=-0.493, \mathrm{r}=-0.466$ and $\mathrm{r}=-0.459$, respectively $)$.

The relationship between periphytic assemblages and the water parameters were confirmed by CCA ordination with total variation of 0.58677 and explanatory variables accounting for $33.8 \%$. It showed positive correlations between temperature and primarily F. capucina and G. olivacea, as well as between EC, nutrients and A. pyrenaicum and $P$. crispa (Fig. 6). Negative relationships, in turn, were between the whole group Chlorophyta, dominating species $K$. mucicola and, H. abundans, T. tabulata, P. lanceolatum, $N$. commutata and the most of water parameters.

\section{Discussion}

According to the general provisions of international law, the natural resources of this region may only be used for peaceful and scientific purposes (Antarctic Treaty 1959). These resources are all the more valuable due to their uniqueness and therefore should be subject to special protection (The Protocol on Environmental Protection to the Antarctic Treaty signed in Madrid on October 4, 1991; Convention on the protection of Antarctic seals signed in London on June 1, 1972; Convention on the conservation of Antarctic

Table 5 Statistically significant Spearman coefficient correlation between species of periphytic assemblages and physiochemical water parameters $(\mathrm{N}=20, \mathrm{p}<0.05)$ in small water bodies and streams studied in Antarctic summer (March/April 2019)

\begin{tabular}{|c|c|c|c|c|c|c|}
\hline Species/water parameters & $\mathrm{pH}$ & $\mathrm{T}$ & $\mathrm{TN}$ & $\mathrm{N}-\mathrm{NH}_{4}$ & $\mathrm{P}-\mathrm{PO}_{4}$ & $\mathrm{TP}$ \\
\hline Achnanthidium pyrenaicum & & & 0.481 & & & \\
\hline Planothidium lanceolatum & -0.531 & & & & & \\
\hline Gomphonella olivacea & & & & & -0.571 & -0.493 \\
\hline Keratoccoccus тисісоla & & & & -0.493 & & \\
\hline Navicula cryptocephala & & & & & -0.478 & \\
\hline Pinnularia divergens & & & & & & -0.466 \\
\hline Pinnularia obscura & & & & & -0.529 & -0.459 \\
\hline Planktothrix agardhii & & -0.458 & & & & \\
\hline
\end{tabular}

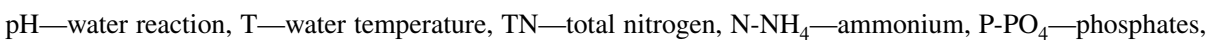
TP_total phosphorus 


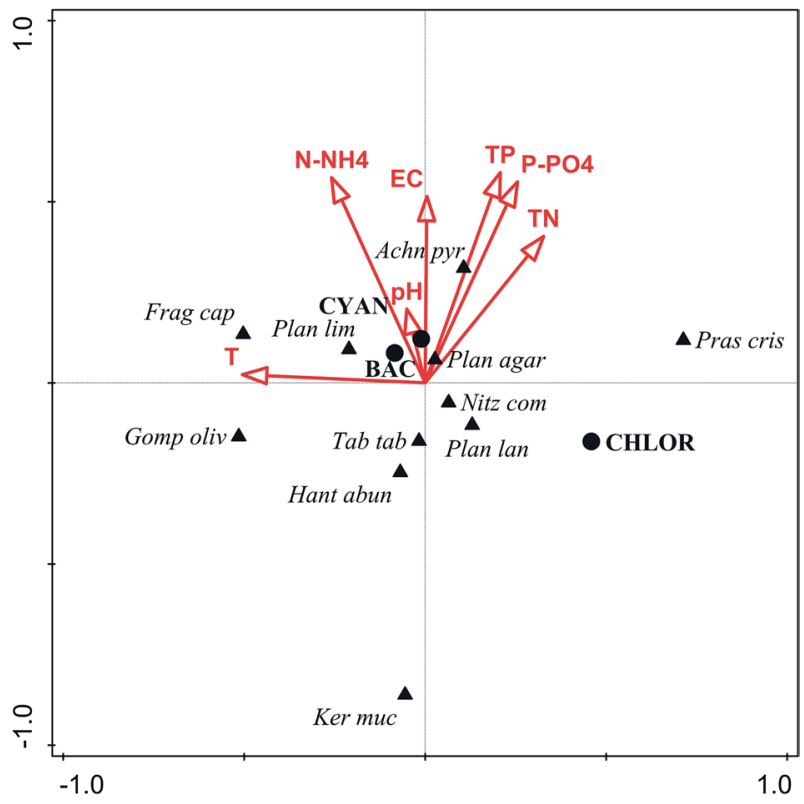

Fig. 6 The ordination biplot diagram of CCA for periphytic assemblages of mats and water variables in the small water bodies and streams. Directions of vectors indicate positive (the same direction), negative (an opposite directions) or near zero (crossing at right angles) correlations. Codes of variables: CYANCyanobacteria, BAC-Bacillarophyta, CHLOR-Chlorophyta, Achn pyr-Achnanthidium pyrenaicum, Frag cap-Fragilaria capucina, Plan lan-Planothidium lanceolatum, Tab tab-Tabularia tabulata, Gomp oliv-Gomphonella olivacea, Hant abun-Hantzschia abundans, Nitz com-Nitzschia commutata, Pras cris-Prasiola crispa, Ker muc-Keratococcus mucicola, Plan lim-Planktolyngbya limnetica, Plan agarPlanktothix agardhii; $\mathrm{pH}$-water reaction, T-water temperature, EC — electrolytic conductivity, N-NH4ammonium, TN_total nitrogen, $\mathrm{P}-\mathrm{PO} 4$ - phosphates, TP-total phosphorus

marine living resources signed in Canberra on May 20, 1980; Marciniak 2017; Świątecki et al. 2019). In the doctrine of international law, the protection of these resources should be in accordance with the principle of sustainable development, i.e. in such a way that they can be used by modern generations and at the same time remain for future generations. It is therefore important to prevent pollution and degradation of these natural resources, the more so as Antarctica's management system is solely based on the environment (Nowlan 2001; Hemmings 2010). Especially after the entry into force of the Madrid Protocol, some authors believe that the principles governing the Antarctic legal regime have in fact acquired an "ecological vector" (Rothwell 2000; Hemmings and Kriwoken 2010). According to Article 7 of the Treaty to achieve these goals, special protective measures should be planned and developed in Antarctica to avoid anthropogenic environmental impact, including through the prohibition of any activity on the industrial development of mineral resources. An exception is provided for scientific research (Goldsworthy and Hemmings 2008). In addition, international legal regulation of the Antarctic mineral resources regime was supposed to be governed by the Convention on the Regulation of Mineral Resources of Antarctica (1988). The main idea and purpose of the Convention is that the development of resources should not cause any harm to the natural environment. It is controlled by the establishment of conditions and procedures for the development and production of mineral resources. Nevertheless, there is a problematic issue regarding the use of these resources. 
Most likely, some industrialized countries with territorial claims in Antarctica without their own resources will expand the scope of research work to uncover the prospects of using the region's mineral resources (Lagoni 1979; Brazovskaya and Ruchkina 2020). This may become a real threat to these resources and contribute to their further degradation.

The biggest problem for polar ecosystems is global climate change (Turner et al. 2013; Ciechanowicz-McLean 2017), caused by the accumulation of greenhouse gases in the troposphere, i.e. carbon dioxide and methane, which contribute to climate warming. All the more so as greenhouse gas emissions are likely to be evident at a variety of scales, both temporally and spatially (Parry et al. 2007). Furthermore, in the Antarctic, changes in stratospheric ozone are now also thought to have contributed to observed climate change effects (Thompson and Solomon 2002), with the interaction effects of ozone and $\mathrm{CO}_{2}$ increasingly recognized as important (Mayewski et al. 2009; Turner et al. 2013). A consequence of this phenomenon is an increase in temperature, which causes gradual melting of glaciers and other climatic anomalies (Convey and Smith 2006; Bosello et al. 2007; Szafraniec 2018; Lowry et al. 2019; Świątecki et al. 2019). Temperature variation studies over 50 years (1971-2000) showed an increasing trend at a rate of $0.56^{\circ} \mathrm{C}$ per decade over the year and $1.09^{\circ} \mathrm{C}$ per decade during the winter (Turner et al. 2005). Another study confirmed that the Antarctic ice sheet is losing $152 \mathrm{~km}^{2}$ of ice per year as a consequence of a $2^{\circ} \mathrm{C}$ increase in temperature (Serreze et al. 2007). Climate changes contribute to changes in environmental conditions, especially water temperature and trophy (Castini et al. 2008; Trathan and Agnew 2010), which are visible in the species structure-the disappearance of cold-loving (sub-Arctic) species, which are becoming endangered species in favor of those commonly occurring in the temperate zone. Cyanobacteria have been able to adapt to climate changes as well as anthropogenic disturbances. These organisms exhibit the widest range of diversity of growth habitats and have developed $\mathrm{CO}_{2}$ concentration mechanisms that adapt them to various environmental constraints (Chaurasia 2015). These rich natural resources are subjected to degradation due to global warming and pollution, thus, Antarctic regions are becoming the subject of scientific research by climatologists and biologists. The Antarctic Peninsula has some of the highest footprint values, in particular the ice-free areas where many stations and tourist attractions are concentrated, in particular King George Island with over 90 footprints on an area of approx. $4.5 \mathrm{~km}^{2}$. The footprint maps show intense human activity in the area, which is associated with the exploration and pollution of the polar environment. It is therefore necessary to establish monitoring the programs for anthropogenic activities, environmental damage and non-native species (Pertierra et al. 2017). An example of the research institution is Arctowski Polish Antarctic Station at the King George Island.

The climate-related changes may affect the environmental conditions of water bodies especially lead to a higher trophy (Castini et al. 2008). In this study, the lowest average water temperature was noted in streams than in small water bodies in Antarctic summer (March/April) 2019. This fact is due to the outflow of water from the glacier feeding the water in the streams. High values of electrolytic conductivity (max. above 1000 $\mu \mathrm{S} \mathrm{cm}{ }^{-1}$ ) and nutrient concentration (TP, TN, N-NH$H_{4}$ and $\mathrm{P}^{-\mathrm{PO}_{4}}$ ) in studied streams and small water bodies were also recorded. Moreover, the five-time higher $\mathrm{TP}$ and $\mathrm{PO}_{4}$ values were in the streams than small water bodies. It all confirms that Antarctic environment were characterized by the high nutrient concentrations. Namely, some authors recorded similar nutrient concentrations $\left(3 \mathrm{mg} \mathrm{L}^{-1} \mathrm{TN}\right.$ and $\left.4 \mathrm{mg} \mathrm{L}^{-1} \mathrm{TP}\right)$ near snow fields, snow-fed streams of small to intermediate size and glacial rivulets running continuously during the summer season in this region. The snow-fed streams are the most common and diverse freshwater ecosystems (Elster and Komarek 2003). However, their 
nutrient content, and therefore water trophic status, could be increased from external nutrient sources like bird colonies as e.g. penguins or by increased weathering of rocks (Vincent and Laybourn-Parry 2008; Kviderova and Elster 2013).

The cause of high nutrient content is eutrophication, even in Antarctic water ecosystems. The high trophy of water reservoirs is a factor favoring the growth of periphyton organisms (Rosemond 1993; Smith et al. 1999; Hillebrand 2002). In this study, it was indicated by the higher wet and dry weight of the stream mats at higher water trophy in comparison to the small water body mats. In addition, the higher variability of these values in the streams may be related to the greater dynamics of these waters caused by the inflow of water from the glacier. Similarly, the three-time higher total biomass of cyanobacteria and periphytic algae on microbial mats was found in the streams at high $\mathrm{N}$ and $\mathrm{P}$ contents than in the small water bodies.

Environmental conditions shape the structure and species composition of periphytic algae. In this study, the structure and species composition of the cyanobacteria and algal biomass was differentiated among the studied small water bodies and streams. Cyanobacteria, Bacillariophyta and Chlorophyta are the main representatives of periphytic assemblages inhabiting the microbial mats. The higher biomass dominance of Cyanobacteria was found in streams at six sites (max. above $90 \%$ of the total biomass) while this group dominated only at one site in the small water bodies (max. 57\%). Diatoms reached the highest proportion in total biomass in the small water bodies (above 90\%), whereas green algae in streams (up to 70-80\%) with one exception with a high proportion of $66 \%$ at one site in the small water bodies. The domination of these three groups in the periphyton assemblages was also recorded by the other authors (Vinocur and Pizarro 1995, 2000). We suggest, that the recorded higher dominance of cyanobacteria in streams may be related to the higher water trophy. Similarly, Makhalanyane et al. (2015) also recorded the presence of cyanobacteria at extreme polar conditions, particularly with a high nitrogen concentration. Cyanobacteria were mainly represented by filamentous Planktothix agardhii (V class) accompanied by Planktolyngbya limnetica, Pseudanabaena catenata, Oscillatoria sancta and Microcoleus autumnalis with the proportion not exceeding $20 \%$ of the total biomass. Among diatoms, the most abundant was Fragilaria capucina especially on the small water body mats with maximum almost 80\%. Other dominants were Planothidium lanceolatum, Achnanthidium pyrenaicum, Tabularia tabulata, Pinnularia microstauron, Gomphonella olivacea, Hantzschia abundans and Nitzschia commutata. Some authors also identified similar periphyton taxa (of the genera Fragilaria, Navicula, Tabellaria, Nitzschia) which colonized the artificial substrates in this Antarctic region (Segovia-Rivera and Valdivia 2016) and natural ones in subarctic lake (Maltais and Warwick 1997). P. borealis and F. capucina was also noted in the island King George Island (Vinocur and Pizarro 2000). In this study, chlorophytes were represented by Prasiola crispa (V class) at stream and Keratococcus mucicola (IV class) at small water body. Similar to this study, other researches was found Prasiola crispa in microbial mats (Vinocur and Pizarro 1995, 2000; Ferreira da Silva et al. 2019). This species often occurred in the places of the inflow of water from the vicinity of penguins. P. crispa is considered to be ornithocoprophilic, it presents a significant biomass mainly around penguin colonies, where the availability of nutrients for both green algae and the surrounding diatoms is higher compared to other habitats (Putzke and Pereira 2001). Moreover, this species is a natural substrate for smaller algae, e.g. diatoms. Thus, it constitutes a unique environment for the periphytic algae of small Antarctic water bodies. We suggest that a large share of periphytic species commonly occurring, e.g. Planktothix agardhii, Planktolyngbya limnetica, Fragilaria 
capucina and Gomphonella olivacea, and limiting the typically polar ones, may indicate the progressive changes in the eutrophication of Antarctic waters.

Generally, the lowest biodiversity were noted on mats in the region of moraine stream of the Ecology Glacier, whereas the highest on mats in the Petrified Forest Stream. The majority of dominant species inhabiting the Antarctic mats are recognized as commonly found worldwide also in freshwater phytoplankton. Referring these species to functional patterns, it was found that they can be the representatives of at least five functional coda S1, T $\mathrm{B}$, MP, D and P (Reynolds et al. 2002; Padisák et al. 2009). Planktothix agardhii and Planktolyngbya limnetica are typical of turbid mixed environments and known as shadeadapted cyanobacteria (codon S1). Thus, their mass occurrence was primarily confirmed for side moraine stream of the Ecology Glacier. The various taxa of the genera Achnanthidium, Planothidium, Gomphonella, Navicula are representatives of codon $\mathrm{T}_{\mathrm{B}}$ and usually occur in highly lotic environments (streams and rivulets). Cyanobacteria Oscillatoria sancta and Pseudanabaena catenata are representatives of codon MP and typical of frequently stirred up, inorganically turbid shallow small water bodies. Tabularia tabulata and species of the genus Nitzschia are often noted in shallow turbid waters including rivers (codon D). Diatom Fragilaria capucina represents codon P with habitat template of continuous or semi-continuous mixed layer of 2-3 $\mathrm{m}$ in thickness at higher trophic states and its mass occurrence was highly related to small water body environment in Ornithologists reservoir system. The cluster analysis of taxonomic structure of periphytic assemblages indicated also a high similarity of sites situated in these small water bodies and streams on the slope of Upłaz moraine. Completely differently were grouped mats from sites of side moraine stream of the Ecology Glacier, area with penguin colony and some sites from Petrified Forest Stream and one in Czech creek with cyanobacteria Planktothix agardhii and Planktolyngbya limnetica as dominants. And lastly, similarly-connected mats primarily with a high biomass of chlorophytes Prasiola crispa and Keratococcus mucicola, and diatom Tabullaria tabulata came from rest of the studied sites (including Petrified Forest Stream, Czech creek, penguin area and inflow to the drinking water reservoir).

The important factors determining the growth of periphytic assemblages were water temperature and the availability of nutrients in the water. In the case of cyanobacteria, the main ecological factors influencing their growth is water temperature over $0^{\circ} \mathrm{C}$ in Antarctica (Komárek 2013). Cyanobacteria dominated at the average temperature of $2.4^{\circ} \mathrm{C}$ in King George Island (Vinocur and Pizarro 2000). An increase in the rate of cyanobacteria photosynthesis at increasing temperature in icy habitats was also observed (Fritsen and Priscu 1998). Moreover, periphytic algae are more sensitive to UV stress at low water temperature in ice streams. Generally, low temperatures slow down the growth rate of algae. However, it was observed a marked increase in the periphytic algae biomass at low turbidity and the lack of ice cover in the spring season (Uehlinger et al. 2009). Some authors recorded correlation between periphytic species and nutrient concentrations, indicating the uptake N and P by algae (Francoeur et al. 1999; Steinman et al. 1995; Dodds and Welch 2000; Mulholland and Webster 2010). In this study, the CCA analysis shows that the water temperature favors the growth of $F$. capucina and G. olivacea while nutrient concentrations stimulate $A$. pyrenaicum and $P$. crispa. Moreover negative relationships between the whole group Chlorophyta, dominating species $K$. mucicola and, H. abundans, T. tabulata, $P$. lanceolatum, $N$. commutata and nutrients suggest the phenomenon of uptake these elements from the water. This tendency was confirmed by statistically significant correlation between some cyanobacteria and algal biomass, and water temperature and nutrient concentrations. A. pyrenaicum was positively correlated with TN. Moreover $P$. agardhii was negatively correlated with water temperature. This species reached the highest biomass in 
streams at the lowest mean water temperature. However, the negatively correlation between K. mucicola and $\mathrm{N}_{-} \mathrm{NH}_{4}$, G. olivacea, N. cryptocephala, P. obscura and $\mathrm{P}_{-} \mathrm{PO}_{4}$, and G. olivacea, $P$. divergens, $P$. obscura and TP indicated the uptake of these elements from the water.

\section{Conclusions}

In summary, Antarctic environments have unique characteristics with different abiotic factors and specific substrates, creating the habitats for the periphytic organisms in small water reservoirs (small water bodies, streams), which often are formed as a result of melting glaciers. The significantly diversified periphytic assemblages between the microbial mats of small water bodies and streams indicated a great variability of environmental conditions, especially in streams. The structure of periphytic assemblages was mainly determined by the type of substrate and the physicochemical parameters of the water. Our results suggest the phenomenon of nutrient uptake by periphytic cyanobacteria and algae from the waters, confirmed by the negative correlations between some species and nutrients (TN, TP, N-NH $4, \mathrm{P}_{4} \mathrm{PO}_{4}$ ). We also suggest that a large share of periphytic species commonly occurring and limitation of typically polar ones, indicate progressive changes in the eutrophication of Antarctic waters caused by the global climate change and increase in the environmental pollution. Due to the global changes in the environment, these areas should be subjected to a special protection, preceded by detailed research, and should be left over by areas not under the jurisdiction of any country, because only this way it will be possible to preserve such a unique and valuable ecosystem for future generations.

Acknowledgements The research was funded within the grant of NCN no. 2017/25/B/NZ8/01915. Analyses and preparation of manuscript were partly supported by the Faculty of Law and Administration, University of Warmia and Mazury (statutory research topic no. 24.610.044-110) and by the S. Sakowicz Inland Fisheries Institute in Olsztyn (SSIFI statutory research topic no. S-009).

Author contributions EZ: Conceptualization, Methodology, Formal analysis, Writing-Original Draft; AN-K: Conceptualization, Methodology, Formal analysis, Investigation, Writing-Original Draft, Visualization; AŚ: Conceptualization, Methodology, Investigation, Resources, Funding acquisition; DG: Conceptualization, Methodology, Investigation, Resources, Funding acquisition. All authors provided critical feedback on the whole manuscript.

Funding The research was funded within the grant of NCN no. 2017/25/B/NZ8/01915. Analyses and preparation of manuscript were supported by the Faculty of Law and Administration, University of Warmia and Mazury (statutory research topic no. 24.610.044-110) and by S. Sakowicz Inland Fisheries Institute in Olsztyn (SSIFI statutory research topic no. S-009).

Availability of data and material Data are available by authors only for request.

\section{Declarations}

Conflict of interest The authors declare that they have no conflicts of interest.

Open Access This article is licensed under a Creative Commons Attribution 4.0 International License, which permits use, sharing, adaptation, distribution and reproduction in any medium or format, as long as you give appropriate credit to the original author(s) and the source, provide a link to the Creative Commons licence, and indicate if changes were made. The images or other third party material in this article are included in the article's Creative Commons licence, unless indicated otherwise in a credit line to the material. If material is not included in the article's Creative Commons licence and your intended use is not 
permitted by statutory regulation or exceeds the permitted use, you will need to obtain permission directly from the copyright holder. To view a copy of this licence, visit http://creativecommons.org/licenses/by/4.0/.

\section{References}

Antarctic Treaty System (ATS) signed at Washington on December 1, 1959 (LJ of 1961, no. 46, item 237)

Battarbee RW (1979) Diatoms in lake sediments, in: International Geological Correlation Program Project 158, Paleohydrological Changes in the Temperate Zone in the Last 15,000 Years. Subproject B, Lake and Mire Environments. Dept. of Quaternary Geology, Lund, Sweden

Biggs BJF (2000) Eutrophication of streams and rivers: dissolved nutrient-chlorophyll relationships for benthic algae. J North Am Benth Soc 21:17-31

Bosello F, Roson R, Tol RSJ (2007) Economy-wide estimates of the implications of climate change: sealevel rise. Environ Res Econom 37:549-571

Braun M, Gossmann H (2002) Glacial changes in the areas of Admiralty Bay and Potter Cove, King George Island, Maritime Antarctica. In: Beyer L, Bolter M. (Eds.), Geoecology of Antarctic icefree coastal landscapes. Ecological studies, 154, Springer, Berlin, pp 75-89

Brazovskaya YE, Ruchkina GF (2020) Current Human Impact on Antarctic Seabed Environment and International Law. The Law of the Seabed, Access, Uses, and Protection of Seabed Resources Series: Publications on Ocean Development 90:125-135. https://doi.org/10.1163/9789004391567_ 008

Cannone N, Convey P, Malfasi F (2018) Antarctic Specially Protected Areas (ASPA): a case study at Rothera Point providing tools and perspectives for the implementation of the ASPA network. Biodivers Conserv 27:2641-2660. https://doi.org/10.1007/s10531-018-1559-1

Castini M, Lovgren J, Hjelm J, Cardinale M, Molinero JC, Kornilovs G (2008) Multi-level trophic cascades in a heavily exploited open marine ecosystem. Philos Trans R Soc Lond B275:1793-1801

Chaurasia A (2015) Cyanobacterial biodiversity and associated ecosystem services: introduction to the special issue. Biodivers Conserv 24:707-710. https://doi.org/10.1007/s10531-015-0908-6

Ciechanowicz-McLean J (2017) Węzłowe problemy prawa ochrony klimatu [The key issues of climate protection law]. Studia Prawnoustrojowe 37:8-24

Convention on the protection of Antarctic seals signed in London on June 1, 1972 (LJ of 1980, no. 28, item 119, 120)

Convention on the conservation of Antarctic marine living resources signed in Canberra on May 20, 1980 (LJ of 1984, no. 61, item 314)

Convey P, Smith RIL (2006) Responses of terrestrial Antarctic ecosystems to climate change. Plant Ecol 182:1-10. https://doi.org/10.1007/s11258-005-9022-2

Dodds WK, Welch EB (2000) Establishing nutrient criteria in streams. J N Am Benthol Soc 19:186-196

Elster J, Komarek O (2003) Ecology of periphyton in a meltwater stream ecosystem in the maritime Antarctica. Antarct Sci 15:189-201

Ferreira da Silva J, Oliveira Linton MA, Ribeiro da Anunciacão R, Pereira da Silva E, Alves RP, Schunemann AL et al (2019) Distribution of aerophilous diatom communities associated with terrestrial green macroalgae in the South Shetland Islands. Maritime Antarctica Plos ONE 14:12

Francoeur SN, Biggs BJF, Smith RA, Lowe RL (1999) Nutrient limitation of algal biomass accrual in streams: seasonal patterns and a comparison of methods. J N Am Benthol Soc 18:242-260

Fritsen CH, Priscu JC (1998) Cyanobacterial assemblages in permanent ice covers of Antarctic lakes: distribution, growth rate, and temperature response of photosynthesis. J Phycol 34:587-597

Gawor J, Grzesiak J, Sasin-Kurowska J, Borsuk P, Gromadka R, Górniak D, Świątecki A, AleksandrzakPiekarczyk T, Zdanowski M (2016) Evidence of adaptation, niche separation and microevolution within the genus Polaromonas on Arctic and Antarctic glacial surfaces. Extremophiles 20:403-413

Goldsworthy L, Hemmings AD, (2008) The Antarctic Protected Area approach. In: Hart S. (Ed.), Shared resources: Issues of governance. Environmental Policy and Law Paper 72, Gland, Switzerland, pp $105-128$

Grzesiak J, Zdanowski M, Górniak D, Świątecki A, Aleksandrzak-Piekarczyk T, Szatraj K, SasinKurowska J, Nieckarz M (2015) Microbial community changes along the Ecology Glacier ablation zone (King George Island, Antarctica). Polar Biol 38:2069-2083

Grzesiak J (2017) Effects of climate change on microbial community structure and function in the antarctic glacier lagoon. Papers on Global Change 17:7-15 
Hemmings AD (2010) Environmental Law-Antarctica, in: Berkshire Encyclopedia of Sustainability: The Law And Politics Of Sustainability, Berkshire Publishing Group, pp. 188-194

Hemmings AD, Kriwoken LK (2010) High-level Antarctic EIA under the Madrid Protocol: State practice and the effectiveness of the comprehensive environmental evaluation process. Int Environ Agreements 10(3):187-208

Hillebrand H (2002) Top-down vs bottom-up control of autotrophic biomass: a meta-analysis on experiments with periphyton. J N Am Benthol Soc 21:349-369

Komárek J (2013) Phenotypic and ecological diversity of freshwater coccoid cyanobacteria from maritime Antarctica and islands of NW Weddell Sea. I Synechococcales Czech Polar Reports 3(2):130143. https://doi.org/10.5817/CPR2013-2-14

Komulaynen S (2009) Diatoms of periphyton assemblages in small rivers in Northwestern Russia. Stud Trent Sci Nat 84:153-160

Kviderova J, Elster J (2013) Standardized algal growth potential and/or algal primary production rates of maritime Antarctic stream waters (King George Island, South Shetlands). Polar Res 32:11191. https:// doi.org/10.3402/polar.v3210.11191

Lagoni R (1979) Antarctica's s Mineral Resources in International Law. Zeitschrift für ausländisches öffentliches Recht und Völkerrecht. Heidelberg Journal of International Law 39:1-37

Lowry P, Golledge NR, Menviel L, Bertler AN (2019) Deglacial evolution of regional Antarctic climate and Southern Ocean conditions in transient climate simulations. Clim past 15:189-215

Makhalanyane TP, Valverde A, Velázquez D, Gunnigle E, van Goethem MW, Quesada A, Cowan DA (2015) Ecology and biogeochemistry of cyanobacteria in soils, permafrost, aquatic and cryptic polar habitats. Biodivers Conserv 24:819-840. https://doi.org/10.1007/s10531-015-0902-z

Marciniak KJ (2017) System Układu Antarktycznego, uwagi z perspektywy prawa międzynarodowego [Antarctic Treaty System in the international law perspective], in: Układ Antarktyczny. Wybór dokumentów z wprowadzeniem [Antarctic Treaty. Selection of documents with an introduction]. MSZ, Warszawa, pp 15-58

Mayewski PA, Meredith MP, Summerhayes CP, Turner J, Worby A, Barrett PJ, Casassa G, Bertler NAN, Bracegirdle T, Garabato ACN, Bromwich D, Campbell H, Hamilton GS, Lyons WB, Maasch KA, Aoki S, Xiao C, Van Ommen T (2009) State of the Antarctic and Southern Ocean climate system. Reviews of Geophyics, 47, RG1003

Maltais M-J, Warwick FV (1997) Periphyton community structure and dynamics in a subarctic lake. Can J Bot 75:1556-1569

Mieczan T, Tarkowska-Kukuryk M, Górniak D, Świątecki A, Zdanowski M, Adamczuk M (2013) Vertical microzonation of ciliates in cryoconite holes in Ecology Glacier. King George Island Pol Polar Res 34(2):201-212. https://doi.org/10.2478/popore-2013-0008

Mulholland PJ, Webster JR (2010) Nutrient dynamics in streams and the role of J-NABS. J N Am Benthol Soc 29:110-117

Napiórkowska-Krzebietke A, Kobos J (2016) Assessment of the cell biovolume of phytoplankton widespread in coastal and inland water bodies. Water Res 104:532-546. https://doi.org/10.1016/j.watres. 2016.08.016

Nowlan L (2001) Arctic Legal Regime for Environmental Protection. Environ Policy Law 44:1-85

Padisák J, Crossetti LO, Naselli-Flores L (2009) Use and misuse in the application of the phytoplankton functional classification: a critical review with updates. Hydrobiologia 621:1-19. https://doi.org/10. 1007/s10750-008-9645-02009

Parry L, Canziani OF, Palutikof JP, Van Der Linden PJ, Hanson CE (Eds.) (2007) Climate change 2007: impacts, adaptation and vulnerability. Contribution of Working Group II to the Fourth Assessment Report of the Intergovernmental Panel on Climate Change, Cambridge University Press, Cambridge

Pertierra LR, Hughes KA, Vega GC, Olalla Ta'rraga MA' (2017) High Resolution Spatial Mapping of Human Footprint across Antarctica and Its Implications for the Strategic Conservation of Avifauna. PLoS ONE 12(1): e0168280

Pielou EC (1966) The measurement of diversity in different types of biological collections. J Theor Biol 13:131-144

Putzke J, Pereira AB (2001) The Antarctic mosses, Editorial ULBRA, Canoas, Brazil

Rakusa-Suszczewski S (2005) Aktualny stan i perspektywy rozwoju badań antarktycznych w Polsce [Current status and development perspectives of Antarctic research in Poland]. Nauka 2:119-128

Reynolds CS, Huszar V, Kruk C, Naselli-Flores L, Melo S (2002) Towards a functional classification of the freshwater phytoplankton. J Plankton Res 24(5):417-428. https://doi.org/10.1093/plankt/24.5.417

Rosemond AD (1993) Interactions among irradiance, nutrients, and herbivores constrain a stream algal community. Oecologia 94:585-594 
Rothwell DR (2000) Polar Environmental Protection and International Law: The 1991 Antarctic Protocol. Eur J Int Law 11(3):591-614. https://doi.org/10.1093/ejil/11.3.591

Segovia-Rivera V, Valdivia N (2016) Independent effects of grazing and tide pool habitats on the early colonization of an intertidal community on western Antarctic Peninsula. Rev Chil Hist Nat 89:3. https:// doi.org/10.1186/s40693-016-0053-y

Serreze MC, Holland MM, Stroeve J (2007) Perspectives on the Arctic's Shrinking Sea-Ice-Cover. Science 315:1533-1536

Shannon CE (1948) A mathematical theory of communication. The Bell System Technical Journal 27:379423 and 623-656

Smith VH, Tilman GD, Nekola JC (1999) Eutrophication: impacts of excess nutrient inputs on freshwater, marine, and terrestrial ecosystems. Environ Pollut 100:179-196

Steinman AD, Mulholland PJ, Beauchamp JJ (1995) Effects of biomass, light, and grazing on phosphorus cycling in stream periphyton communities. J N Am Benthol Soc 14:371-381

Stevenson RJ, Rier ST, Riseng CM, Wiley SRE, MJ, (2006) Comparing effects of nutrients on algal biomass in streams in two regions with different disturbance regimes and with applications for developing nutrient criteria. Hydrobiologia 561:149-165

Świątecki A, Górniak D, Jankowska K, Zdanowski M, Borsuk P, Żmuda-Baranowska M, Grzesiak J (2012) Effects of climate change on microbial community structure and function in the antarctic glacier lagoon. Papers on Global Change 17:7-15

Świątecki A, Górniak D, Zdanowski M, Grzesiak J, Mieczan T (2019) Polityczne i prawne aspekty prowadzenia badań naukowych $w$ rejonach polarnych [Political and legal aspects of conducting scientific research in polar regions]. Studia Prawnoustrojowe 43:335-347

Symonides J (2008) Status prawny i roszczenia do Arktyki oraz Bieguna Północnego [Legal status and claims to the Arctic and the North Pole]. Państwo i Prawo 734

Szabo KE, Acs E, Kiss KT, Eiler A, Makk J, Plenkovic-Moraj A, Toth B, Bertilsson S (2007) Periphytonbased water quality analysis of a large river (River Danube, Hungary): exploring the potential of molecular fingerprinting for biomonitoring-Large Rivers 17 (3-4). Arch Hydrobiol 161(3-4):365-382

Szafraniec J (2018) Deglaciation rate on southern and western Spitsbergen in the conditions of Arctic amplification. Pol Polar Res 39:177-198

The Convention on the Regulation of Antarctic Mineral Resource Activities is a treaty that is part of the Antarctic Treaty System adopted at Wellington on 2 June 1988

The Protocol on Environmental Protection to the Antarctic Treaty signed in Madrid on October 4, 1991 (LJ of 2001, no. 6, item 52)

Thompson DWJ, Solomon S (2002) Interpretation of recent Southern Hemisphere climate change. Science 296:895-899

Trathan PN, Agnew D (2010) Climate change and the Antarctic marine ecosystem: an essay on management implications. Antarct Sci 22(4):387-398. https://doi.org/10.1017/S0954102010000222

Turner J, Colwell SR, Marshall GJ, Lachlan-Cope TA, Carleton AM, Jones PD, Lagun V, Reide PA, Iagovkina S (2005) Antarctic climate change during the last 50 years. Int J Climatol 25:279-294. https://doi.org/10.1002/joc. 1130

Turner J, Barrand NE, Bracegirdle TJ, Convey P, Hodgson, DA, Jarvis M, Jenkins A, Marshall G, Meredith MP, Roscoe H, Shanklin J, French J, Goosse H, Guglielmin M, Gutt J, Jacobs S, Kennicutt II MC, Masson-Delmotte V, Mayewski P, Navarro F, Robinson S, Scambos T, Sparrow M, Summerhayes C, Speer K, Klepikov A (2013) Antarctic climate change and the environment: an update. In: Polar Record. Cambridge University Press, Cambridge, pp 1-23. https://doi.org/10.1017/S00322474130002 96

Uehlinger U, Robinson CT, Hieber M, Zah R (2009) The physico-chemical habitat template for periphyton in alpine glacial streams under a changing climate. Hydrobiologia: 05854. https://doi.org/10.1007/ s10750-009-9963-X

Vincent WF, Laybourn-Parry J (eds) (2008) Polar lakes and rivers: limnology of Arctic and Antarctic ecosystems. Oxford University Press, Oxford

Vinocur A, Pizarro H (1995) Periphyton flora of some lotic and lentic environments of Hope Bay (Antarctic Peninsula). Polar Biol 15:401-414

Vinocur A, Pizarro H (2000) Microbial mats of twenty-six lakes from Potter Peninsula, King George Island, Antarctica. Hydrobiologia 437:171-185

Zawidzka-Łojek A (Ed.) (2018) Prawo międzynarodowe publiczne [International public law]. 3 ed., C.H. Beck, Warszawa

Zębek E (2013) Seasonal dynamics of periphytic algae in the vicinity of the hydroelectric plant in the Pasłęka River (north-east Poland). Ecohydrol Hydrobiol 13(3):210-217. https://doi.org/10.1016/j.ecohyd.2013.08.003 
Publisher's Note Springer Nature remains neutral with regard to jurisdictional claims in published maps and institutional affiliations.

\section{Authors and Affiliations}

\section{Elżbieta Zębek ${ }^{1}$ (D) Agnieszka Napiórkowska-Krzebietke ${ }^{2}$ (D) Aleksander Świątecki ${ }^{3}$ (D) . Dorota Górniak ${ }^{3}$ (iD}

Elżbieta Zębek

elzbieta.zebek@uwm.edu.pl

Aleksander Świątecki

aswiat@uwm.edu.pl

Dorota Górniak

gorniak@uwm.edu.pl

1 Department of International Public Law and European Union Law, University of Warmia and Mazury, Obitza 2, 10-725 Olsztyn, Poland

2 Department of Ichthyology, Hydrobiology and Aquatic Ecology, S. Sakowicz Inland Fisheries Institute, Oczapowskiego 10, 10-719 Olsztyn, Poland

3 Department of Microbiology and Mycology, University of Warmia and Mazury, Oczapowskiego 1A, 10-719 Olsztyn, Poland 